\section{Effects of Corporate Social Responsibility on consumer brand loyalty}

\author{
José Javier Rivera ${ }^{1}$ \\ Enrique Bigne ${ }^{1}$ \\ Rafael Curras-Perez ${ }^{1}$ \\ ${ }^{1}$ Faculty of Economics, Department of Marketing, \\ University of Valencia, Valencia, Spain
}

\section{Abstract}

Purpose - This paper analyses the influence of CSR associations on brand loyalty. We propose a theoretical model that includes the mediating role of brand awareness, brand attitude and customer satisfaction in the effect of CSR on loyalty, measured as a second-order reflective construct.

Design/methodology/approach - We propose a theoretical model estimated via the analysis of covariance structures using EQS 6.1. Data were obtained using an online survey of 351 Spanish sportswear consumers.

Findings - This study illustrates that CSR associations have a direct, positive influence on loyalty, and an indirect influence through their positive effect on brand awareness and consumer satisfaction. Brand attitude does not appear to play a significant role in the influence of CSR on loyalty.

Originality/value - We study the effect of CSR associations, brand awareness, satisfaction, and brand attitude as drivers of brand loyalty, conceived as a reflective second-order construct with four dimensions: attitudinal loyalty, purchase intention, expenditure level and intention to recommend. It is important to construct relational marketing strategies that integrate CSR with consumer orientation using the three dimensions of the model validated in the study: brand awareness, satisfaction and brand attitude.

Keywords - Corporate social responsibility, brand loyalty, brand awareness, consumer attitude, consumer satisfaction

\section{Received on}

11/13/2017

Approved on

$11 / 30 / 2018$

\section{Responsible editor:}

Prof. Dr. João Mauricio Gama

Boaventura

\section{Evaluation process:}

Double Blind Review

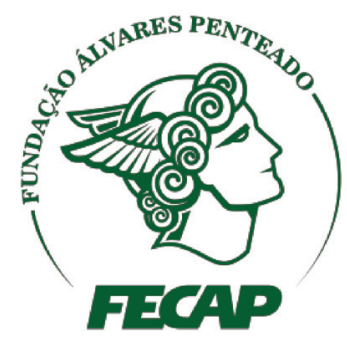

Review of Business Management 


\section{Introduction}

Corporate Social Responsibility (i.e. CSR), understood as the extent to which firms assume economic, legal, ethical, social and discretionary responsibilities vis à vis their stakeholders, can be considered as a marketing tool that, when well managed and communicated, collaborates in the search for differential positioning to stimulate consumer reactions (Maignan, Ferrell \& Hult, 1999; Lacey, Kennett-Hensel \& Manolis, 2015). From the marketing point of view, CSR is different from greenwashing, although sometimes they get confused. CSR involves the proactive integration into the firm's social, environmental or cultural actions of activities that, put into value, are capable of generating positive impacts for the firm and its stakeholders (e.g. consumers). It is, therefore, much more than a communicative reaction (a social or environmental 'facelift'), as a response to poor brand positioning or an image crisis (Chen \& Chang, 2013). Effectively, the literature on CSR (Hoeffler \& Keller, 2002; McWilliams \& Siegel, 2001) supports the idea that pro-social marketing activities can shape a differentiated market strategy for the brand and build brand value (Liu \& al., 2014), which, in turn, might keep consumers loyal.

Thus, CSR is not only an ethical and ideological imperative (Bhattacharya, Korschun \& Sen, 2009; Barrena, López \& Romero, 2016), it is also an economic imperative. In other words, firms are now increasingly aware that social and business realities invite them to design CSR actions; in adopting CSR practices, the firm not only reinforces doing the right thing well, but also doing it better, to have a positive effect on key stakeholders, namely consumers.

Research on the influence of CSR on consumer behaviour has been approached from various angles (Brown \& Dacin, 1997; Maignan, 2001). For example, there is a line of research focused on strictly analysing how the socially responsible brand is perceived by consumers
(Maignan, 2001, Turker, 2009, Alvarado-Herrera et al., 2017). Other works have focused on knowing the antecedents of CSR image formation, such as the attribution of consumer motivations (Forehand \& Grier, 2003), cause-brand fit (Lafferty, 2007) or brand reputation (Dean, 2003). Finally, other studies - with which this article is aligned - have analysed the consequences of CSR perception in the company-consumer relationship, in terms of improving satisfaction (Luo \& Bhattacharya, 2006), perceived value (Alvarado et al., 2010), or the identification of the consumer with the company (Du, Bhattacharya \& Sen, 2007), among others.

Along these lines, the marketing literature and business practices call for a greater understanding of the antecedents of consumer loyalty based on CSR associations (Mandhachitara \& Poolthong, 2011; Martínez, Pérez \& Rodríguez del Bosque, 2014; O’Brien, Jarvis \& Soutar, 2015; Cha, Yi \& Bagozzi, 2016). The research gap involving identifying the antecedents of CSR and how they affect consumer loyalty has been approached through different constructs, such as brand awareness (Du, Bhattacharya \& Sen, 2007; Mohr \& Webb, 2005), brand attitude (He $\& \mathrm{Li}, 2011$ ) and brand satisfaction (Alvarado et al., 2010; Luo \& Bhattacharya, 2006), but with the lack of an integrative approach. This paper bridges the gap by adopting brand loyalty as a reflective second-order construct shaped from the consumer's perspective by attitudinal loyalty, purchase intention, expenditure level and intention to recommend. Therefore, our research goal is twofold. First, it is to analyse the influence of key constructs, such as brand awareness, brand attitude and consumer satisfaction with CSR on multiple brand loyalty effects, namely attitudinal loyalty, purchase intention, expenditure level and word of mouth. Second, we aim to integrate these constructs into a causal model that explains the variables that mediate consumer loyalty.

In sum, this paper contributes to the existing literature by analysing the way CSR 
associations are able to generate consumer loyalty via improving brand equity outcomes (i.e., brand awareness, brand attitude and satisfaction). More specifically, our results provide two interesting insights for both academics and practitioners. First, our findings show a double route of CSR associations towards brand loyalty. Indeed, a direct, positive influence of CSR associations on loyalty is in line with previous literature, but there is also a probably more interesting indirect influence through their positive effect on brand awareness and consumer satisfaction. Second, brand attitude does not have a significant influence on the effect of CSR on loyalty. As will be discussed later on, this controversial result might be explained by two ideas: (i) company social initiatives are demanded as a common rather than an exceptional practice; (ii) at the same time, other consumers are sceptical of the true motives of companies in adopting CSR initiatives, or they are even aware of the lack of companies' social responsibility.

The rest of the paper is organized as follows. First, we review the literature on CSR and consumer behaviour in order to build up a model, which embraces the drivers of CSR and its effect on loyalty and the effects of loyalty in four main variables: attitudinal loyalty, purchase intention, expenditure level and word of mouth. Then, the model is tested using structural equation modelling based on a sample of 351 real sportswear consumers. The following section is devoted to the results and discussion. The paper ends with implications and limitations, as well as future research lines.

\section{Literature Review}

\section{I General conceptual framework of CSR and consumer behaviour}

Evidence of the interest of the business community in the social aspects of company behaviour can be found from the mid-twentieth century (Carroll, 1999; van Marrewijk, 2003).
Since then, conceptualizations of the Corporate Social Responsibility construct have been very diverse. On the one hand, CSR is seen as the reflection of a new social contract between companies and society (van Marrewijk, 2003), while on the other it is seen as a reaction to the social pressures that companies now face (Carroll, 1979). Some of these views see the entrepreneur as the subject of social responsibility (Bowen, 1953; Davis, 1960), and others the organization as a whole (Carroll, 1979; Davis, 1973). Some studies place CSR in the strictly voluntary field (van Marrewijk, 2003) and others see it as obligatory (Bowen, 1953; Frederick, 1960). Some papers emphasize the dimensions or areas for which companies are responsible (Carroll, 1979): it is assumed that companies have responsibilities that go beyond purely maximizing economic benefits. Finally, other studies focus on defining which audiences companies should respond to (Jones, 1980; van Marrewijk, 2003), on the assumption that they should respond not only to their owners, but also to their other stakeholders (Jones, 1980; van Marrewijk , 2003), such as their consumers.

Academic research into the CSR-consumer binomial has basically focused on two lines: on the one hand, operationalizing the CSR construct from the point of view of the consumer (what must the consumer perceive for him/her to consider a company to be socially responsible?); and, on the other hand, an analysis of how the perception of CSR influences the responses of consumers to the company.

Regarding the first point, some papers have tested the multidimensionality of the CSR construct based on Carroll (1979)'s conceptualization, with four CSR dimensions economic, legal, ethical and philanthropic - and the Sustainable Development approach (AlvaradoHerrera et al. 2017), with three dimensions economic, social and environmental. However, the proposal of Brown and Dacin (1997), with its notion of Corporate Associations, is the conceptual framework most used to describe the 
dimensions that constitute CSR as perceived by consumers and to study its subsequent influence on subjects' responses (Du et al., 2007; Sen and Bhattacharya, 2001). Brown and Dacin (1997) distinguish two types of corporate associations: Corporate Ability (CA), which refers to the company's experience in the production and delivery of products and services and is of a predominantly technical nature; and Corporate Social Responsibility (CSR) associations, which "reflect the organization's status and activities with respect to its perceived societal obligations" (p.68), and that relate to non-economic issues. This is the approach followed in this paper.

Regarding the second point, the following main conclusions can be drawn from previous research. Firstly, consumer responses to CSR vary greatly (Lacey et al., 2015). Although it is thought that CSR is basically related to affective consumer responses to the firm (improved brand attitudes, greater identification with the brand and increased affective commitment from consumers), it has been shown that CSR programmes can have purely cognitive effects (e.g., better brand memory and greater awareness) and behavioural effects (e.g., purchase intention, intention to recommend and defence of company image).

Secondly, consumers tend to accept firms' CSR initiatives positively, but are initially sceptical of them (Ellen et al., 2006; Forehand \& Grier, 2003). When a firm presents itself as socially responsible, it modifies the common reference framework of maximising profit, used to evaluate firm behaviour. Through CSR, the firm tries to show a personality characterised, to some extent, by altruistic values. Therefore, consumers begin a process of cognitive elaboration, albeit in a very simple fashion, with one main intention: to acquire guarantees in relation to the firm's good faith in its social commitment and guarantees that the way the firm is presenting itself though its CSR programme is consistent with its real corporate values. This cognitive process is based on a series of basic judgements about the organisation's credibility, its reputation or congruence between the CSR programme, the firm's main activity and its brand positioning (Bigné, Currás \& Aldás, 2012) displayed in advertising, websites and social media.

In this line of research, the literature claims that the firm's different stakeholders, such as consumers, employees and investors, are increasingly inclined to act in ways that reward good CSR practices and also that reject and punish bad CSR practices (Du, Bhattacharya \& Sen, 2010). According to Bhattacharya and Sen (2003), with good CSR practices, firms can encourage loyal customers who will become brand endorsers. It is also claimed that CSR actions do not only improve sales, but also make people consider the firm as an attractive place to work and investors consider the firm as an attractive place for their investment. Thus, CSR encourages the construction of relationships with all stakeholders, expressed through rewards or loyalty (O'Brien et al., 2015).

Thirdly, following Beckmann (2007), it can be said that CSR has many, varied effects on consumers that can only be treated or demonstrated in a diffuse rather than a compact way. In fact, some consumers react to some CSR actions but not others in relation to their level of knowledge of the congruence between consumer and company and product and brand characteristics (Bigné et al., 2012); their reaction also varies with regards to the relationships between corporate skills and CSR actions; and perceived trustworthiness of the information source (Bigné, Chumpitaz \& Currás, 2010). In addition to these consumer-related effects, the effects have also been shown to vary according to the context and cultural, technological, economic, political and social factors (Diehl, Terlutter \& Mueller, 2016).

A recurring theme in the literature is that higher levels of CSR associations are linked to stronger loyalty behaviour because consumers develop a more positive, stronger evaluation of 
the firm (O'Brien et al., 2015). The literature shows that CSR associations are linked to positive consumer evaluations of the brand and products and even to consumer loyalty, (Brown \& Dacin, 1997; Sen \& Bhattacharya, 2001; O’Brien et al., 2015), but there are still gaps in our understanding of the variables that mediate the link between CSR initiatives and consumer loyalty.

\subsection{Proposed theoretical model and hypotheses}

The model proposed in this study is intended to contribute towards filling in the following gaps: (i) how CSR initiatives trigger consumer loyalty; (ii) the role of brand awareness, brand attitude and satisfaction as variables that mediate this influence of CSR on consumer loyalty.

First, the previous research posits that CSR associations improve brand awareness. Aldás, Andreu and Currás (2013) show that CSR has a direct, positive impact on brand awareness which in turn influences brand attitude. Consumer perception of CSR associations is a singular, differentiating brand attribute (Du et al., 2010) that helps to increase awareness by making the brand more memorable and recognisable. Therefore:

\section{H1: Consumer CSR associations directly and positively influence brand awareness.}

CSR associations contribute to improving brand attitude derived from a singular dimension of brand personality (Madrigal \& Bousch, 2008). Du et al. (2007) show that consumers tend to have more positive perceptions of CSR and "reward" CSR actions in terms of attitude. Thus, it is to be expected that social responsibility initiatives will build strong, distinctive brand associations (Hoeffler \& Keller, 2002). Following these ideas, we propose:

H2: Consumer CSR associations directly and positively influence brand attitude.
The literature finds that CSR contributes to consumers' sensation of well-being and social satisfaction and that consumers reward this benefit in the market (Luo \& Bhattacharya, 2006). Bhattacharya and Sen (2004) claim that CSR is a source of satisfaction in that, by experiencing a relationship with the brand engaged in social actions, consumers satisfy their desires and interests in helping to improve the community through their purchase behaviour. García de los Salmones, Herrero and Rodríguez del Bosque (2005) show the direct relationship between social responsibility and the overall evaluation of the service, thereby confirming that responsible behaviour brings commercial benefits for companies.

H3: CSR associations directly and positively influence brand satisfaction.

The literature review confirms the direct, positive influence of brand awareness and satisfaction on brand attitude (Swaen \& Chumpitaz, 2008). CSR appears to have great potential as a generator of brand value due to its ambivalent character. CSR actions therefore generate not only a positive attitude towards the brand, but are also capable of exerting a positive influence on a key element for the brand in mature, globalised markets: its capacity for differentiation. The literature also appears to confirm that the general degree of consumer satisfaction, resulting from the brand's skill at fulfilling consumer desires, expectations and needs, has been identified as a significant antecedent of consumer attitude (Flavián, Guinalíu \& Gurrea, 2006) Therefore:

H4: Brand awareness has a direct, positive influence on brand attitude.

H5: Brand satisfaction has a direct, positive influence on brand attitude.

The different conceptualizations of consumer loyalty given in previous studies 
characterize the construct as a behaviour repeated over time (Jacoby \& Kyner, 1973; Oliver, 1999), as being of a non-random nature in which there is a behavioural response to repurchase the same brand (Ehrenberg et al., 1990), but driven by a favourable attitude towards the brand (Oliver, 1999). That is, consumer loyalty involves a certain degree of involvement and psychological commitment on the part of the consumer towards the brand (Schouten \& McAlexander, 1995), expressed through repeat purchasing behaviour. Loyalty is the result of exogenous factors such as previous experience, satisfaction, attitude, cost, the attractiveness of alternatives and knowledge of and familiarity with the brand (Bennett $\&$ Rundle-Thiele, 2002).

According to Jacoby and Kyner (1973) consumer loyalty is defined by six joint conditions: (1) behaviour; (2) weighted action; (3) expression over time; (4) recognition in decision units; (5) behaviour in relation to one or more alternative brands; and (6) response to a psychological process, based on an evaluation and a decision. The above authors recognise various types of loyalty: behavioural, attitudinal, multi-brand and generic brand.

There is high consensus in the literature that loyalty is a multidimensional construct, with behavioural, affective and social projection subcomponents (Brunner et al., 2008). In this paper, we consider loyalty as a secondorder reflective variable (i.e. multidimensional construct), whose components are purchase intention (behavioural loyalty), attitudinal loyalty, level of expenditure and intention to recommend (Chaudhuri \& Holbrook, 2001). This second-order construct is reflectively related to its dimensions, because the concept of loyalty described by Jacoby and Keyner (1973) and Chaudhuri and Holbrook (2001) demands that these conditions be met in a correlated manner so that loyalty can be produced; or, in other words, it is understood that repeat purchases, attitudinal loyalty, level of expense and WOM are reflections of the psychological and behavioural state of connection with a brand. For example, repeat purchases per se or a certain level of expense, taken in isolation and not correlated with attitude or WOM, should not be understood to be true consumer loyalty. That is why the construct must be considered as reflective, not formative.

Loyalty is one of the marketing variables that are recognised as part of direct consumer responses to CSR perception (Mandhachitara \& Poolthong, 2011; O’Brien et al., 2015). Du et al. (2010) suggest that CSR actions with customer participation could be a tool for gaining new brand loyalty in the sector which can overcome prior loyalty to the leading brand. In contrast, Bhattacharya and Sen (2004) highlight that scepticism over an industry can lead to a low level of awareness of CSR actions as the actions are perceived as non-consistent and provoke distance, non-attitude and non-loyalty for social reasons in relation to the brand. This negative response to CSR can occur for brands that are not credible in the industry, because of their track record, recent events with a negative impact on the community or due to non-values associated with the industry.

\section{H6: CSR associations have a direct, positive influence on brand loyalty.}

The degree of brand awareness will be a direct antecedent of brand loyalty. The more familiar a brand is to consumers, or the more recognition it has in the market, the more likely it is that the brand is included in the choice set of an individual who will consequently develop attitudinal or behavioural loyalty towards the brand. Previous studies (Anisimova, 2007; Hatch \& Schultz, 2003) highlight that brand attributes such as values, personality and degree of awareness are the most critical predictors of attitudinal and behavioural loyalty in consumers (in our model: purchase intention, expenditure level and intention to recommend). Therefore: 
H7: Brand awareness has a direct, positive influence on brand loyalty.

Attitude towards the socially responsible brand is an antecedent of consumer loyalty, which is an output that can be generated by evaluating the attractiveness of the firm's values and social practices, which if positive generate consumer identification with the brand (Marín, Ruiz \& Rubio, 2009; Sen \& Bhattacharya, 2001). Thus, brand attitude is an antecedent of consumer behaviour (reflected in intention to consume the product and use the service) and of brand loyalty (with its different components: attitudinal loyalty, purchase intention, level of expenditure and intention to recommend).

H8: Brand attitude has a direct, positive influence on brand loyalty.
Finally, in the relationship between satisfaction and brand loyalty, Aldás et al. (2013) claim that satisfaction together with trust directly influence consumer loyalty. Crosby and Stephen (1987) claim that satisfaction is an antecedent of the renewal of trust and by extension, of loyalty. Companies with satisfied customers tend to enjoy greater attitudinal loyalty (Bolton \& Drew, 1991; Oliver, 1980), positive word of mouth (Szymanski $\&$ Henard, 2001) and customer desire to pay higher premium prices (Homburg, Koschate \& Hoyer, 2005), all of which can increase the firm's market value. Therefore:

H9: Brand satisfaction has a direct, positive influence on brand loyalty.

To summarize, the literature review provides the basis for the theoretical model considered in this study, illustrated in Figure 1. 


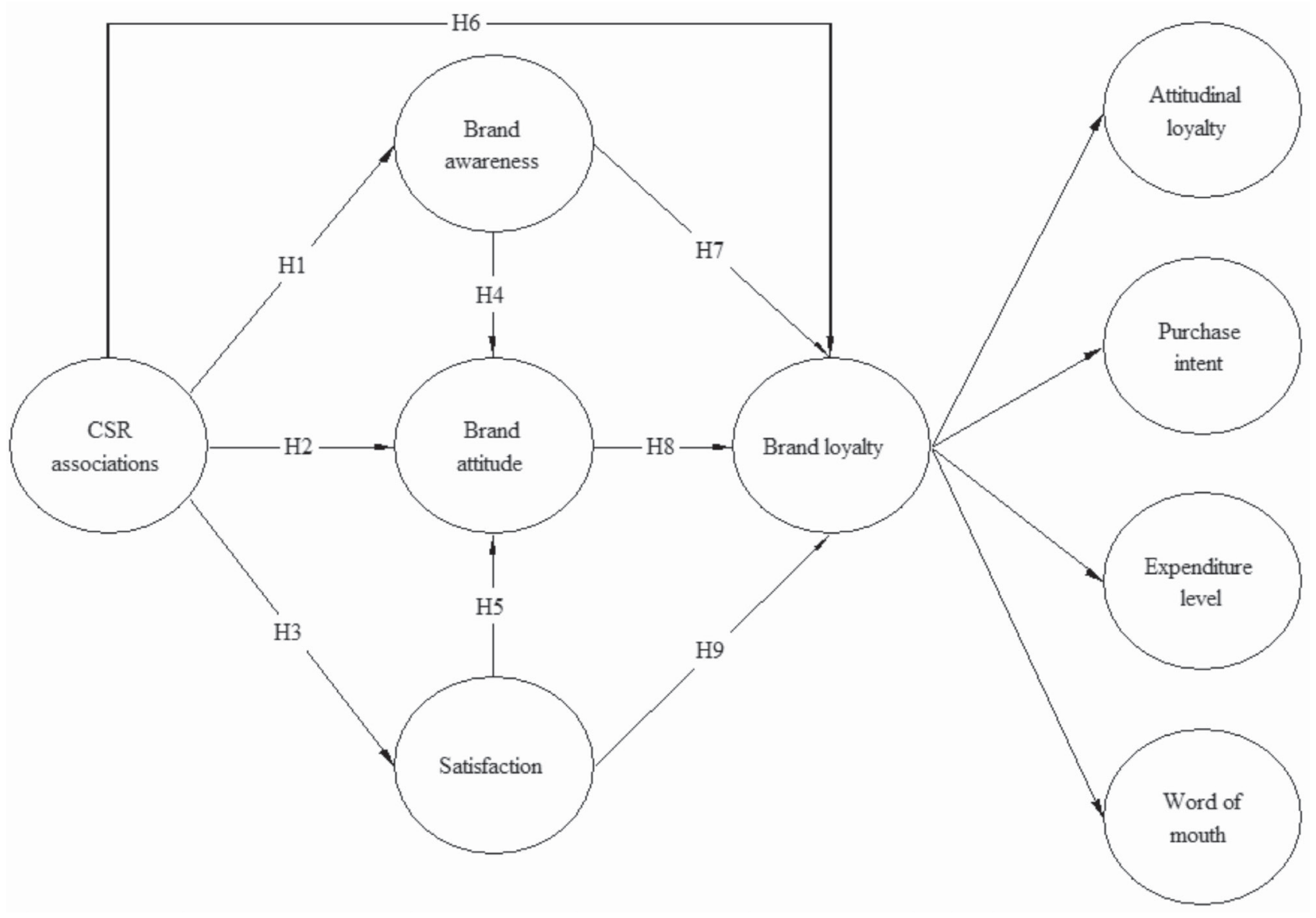

Figure 1. Proposed theoretical model

\section{Methodology}

\section{I Research design, sample selection and information collection}

The research focuses on studying the relationships and the influence that CSR associations provoke in brand awareness, satisfaction, attitude and loyalty. To contrast the model, quantitative empirical research based on an online structured questionnaire was implemented. The estimation was based on the analysis of covariance structures using the EQS 6.1 program. The sportswear fashion sector was chosen to test the proposed model since this sector is dominated by global brands that practice CSR with positive and negative reactions according to consumer behaviour. There is also a distance between the economic importance and the social relevance of the sector (Frenkel, 2001); and finally, the potential for developing CSR in global brands is high, mainly due to the characteristics of the industry, where there is a high risk of violating basic CSR standards (Torres et al., 2012).

The questionnaire was administered online to a panel from a professional company. The interviewees come from all the self-governing regions in Spain. The total sample size was 351 individuals for a confidence level of 95\% $(\mathrm{z}=2)$ and estimation error below $5.2 \%$ for an infinite population in the most unfavourable case of $p=q=0.5$. See Table 1 for the sample's sociodemographic profile. 
Table 1

Sample's sociodemographic profile

\begin{tabular}{|c|c|c|c|}
\hline Variable & Descriptive statistics & Values & $(\%)$ \\
\hline \multirow{2}{*}{ Sex } & Male & 175 & 49.90 \\
\hline & Female & 176 & 50.10 \\
\hline \multirow{5}{*}{ Age } & Between 18 and 24 years old & 66 & 18.80 \\
\hline & Between 25 and 34 years old & 68 & 19.40 \\
\hline & Between 35 and 44 years old & 73 & 20.80 \\
\hline & Between 44 and 54 years old & 73 & 20.80 \\
\hline & Between 55 and 65 years old & 71 & 20.20 \\
\hline \multirow{6}{*}{ Job } & Student & 55 & 15.70 \\
\hline & Self-employed & 28 & 8.00 \\
\hline & Employed & 181 & 51.60 \\
\hline & Retired & 25 & 7.10 \\
\hline & Stay-at-home & 25 & 7.10 \\
\hline & Unemployed & 37 & 10.50 \\
\hline \multirow{5}{*}{ Education } & No formal education & 1 & 0.30 \\
\hline & Basic - Primary - Secondary & 25 & 7.10 \\
\hline & Baccalaureate - Secondary education & 152 & 43.30 \\
\hline & Graduate studies & 76 & 21.70 \\
\hline & Post-graduate studies & 97 & 27.60 \\
\hline \multirow{6}{*}{ Level of Income } & Less than $€ 1000$ & 34 & 9.70 \\
\hline & Between $€ 1000$ and 2000 & 94 & 26.80 \\
\hline & Between $€ 2000$ and 3000 & 91 & 25.90 \\
\hline & Between $€ 3000$ and 4000 & 37 & 10.50 \\
\hline & Over $€ 4000$ & 11 & 3.10 \\
\hline & I prefer not to answer & 84 & 23.90 \\
\hline \multirow{5}{*}{ Frequency of doing sport } & Every day of the week & 35 & 10.00 \\
\hline & 4 to 6 times a week & 130 & 37.00 \\
\hline & 2 to 3 times a week & 146 & 41.60 \\
\hline & Once a week & 21 & 6.00 \\
\hline & Less frequently & 19 & 5.40 \\
\hline
\end{tabular}

In the survey, respondents were requested to identify their preferred sportswear brand, from among ten already selected global-international brands (including two private brands and two distributor brands) in the research. The preferred brand was the one respondents purchased most frequently in the last two years. Then respondents visualized the CSR actions developed by their preferred sportswear brands through text scenarios, in three CSR categories following the Sustainable Development approach: economic, social and environmental activities. Those real activities were obtained from the Sustainability and CSR reports of the ten sportswear brands. Thus, respondents did not assess their general CSR perceptions, but rather their valuation of the CSR actions the companies actually engaged in (according to the published CSR information). Based on consumer reactions to the visualized CSR initiatives, the questionnaire measured the relationships between the CSR actions of each consumer's preferred sportswear brand and the different model variables: consumer satisfaction, brand awareness, attitude and brand loyalty. 


\subsection{Measurement of the variables}

Global, unidimensional scales for the concepts involved were chosen to measure the constructs (see Appendix). All the constructs were measured on 7-point Likert scales. Before the field work, a pilot test was run on the data collection instrument. CSR associations were measured using a battery of 6 items based on the studies by Brown and Dacin (1997) and Sen and Bhattacharya (2001). Brand awareness was approximated using a 5-item scale adapted from Yoo, Donthu and Lee (2000). Brand attitude was measured on a 5-item scale based on Dabholkar and Bagozzi (2002). Consumer satisfaction was measured on the 4-item scale from Cronin, Brady and Hult (2000). Finally, the various measurements of loyalty (attitudinal loyalty: 4 items; purchase intention: 4 items; expenditure level: 3 items; word of mouth: 4 items) were based on the paper by Zeithaml, Berry and Parasuraman (1996).

\subsection{Assessment of measurement instrument psychometric properties}

To assess measurement reliability and validity, a confirmatory factor analysis (CFA) containing all the multi-item constructs in our framework was estimated using EQS 6.1 (Bentler, 2005). Raw data screening showed evidence of non-normal distribution (Mardia's coefficient normalized estimate $=80.77)$. We decided to use the method of correcting the statistics rather than using different estimation methods, so robust statistics (Satorra \& Bentler, 1994) would be provided.

Table 2 shows the main goodness of fit indicators for the measurement model and the values of the indicators calculated to examine the model's psychometric properties. The values for $\mathrm{BBNFI}=.887, \mathrm{BBNNFI}=.941, \mathrm{CFI}=.947$, IFI=.947 and RMSEA=.047 show that the model offers good global fit as the corresponding critical values are exceeded (Hair et al., 2005). 
Table 2

Confirmatory Factor Analysis: reliability and convergent validity

\begin{tabular}{|c|c|c|c|c|c|c|}
\hline \multirow[b]{2}{*}{ Factor } & \multirow[b]{2}{*}{ Item } & \multicolumn{2}{|c|}{ Convergent Validity } & \multicolumn{3}{|c|}{ Reliability } \\
\hline & & Load (robust $t$ value) & Average loads & $\begin{array}{c}\text { Cronbach's } \\
\alpha \\
\end{array}$ & CR & VEI \\
\hline \multirow{6}{*}{$\begin{array}{l}\text { CSR ASSOCIATIONS } \\
\text { (CSR) }\end{array}$} & $\operatorname{csr} 1$ & - & \multirow{6}{*}{, 83} & \multirow{6}{*}{, 92} & \multirow{6}{*}{92} & \multirow{6}{*}{,69 } \\
\hline & $\operatorname{csr} 2$ &, $77(16,33)^{*}$ & & & & \\
\hline & $\operatorname{csr} 3$ &, $84(19,98)^{*}$ & & & & \\
\hline & $\operatorname{csr} 4$ &, $86(18,91)^{*}$ & & & & \\
\hline & $\operatorname{csr} 5$ &, $86(16,16)^{*}$ & & & & \\
\hline & $\operatorname{csr} 6$ &, $82(15,12)^{*}$ & & & & \\
\hline \multirow{5}{*}{$\begin{array}{l}\text { BRAND AWARENESS } \\
\text { (AWA) }\end{array}$} & awa1 &, $71(11,08)^{*}$ & \multirow{5}{*}{, 75} & \multirow{5}{*}{, 84} & \multirow{5}{*}{, 84} & \multirow{5}{*}{, 57} \\
\hline & awa2 &, $81(14,94)^{*}$ & & & & \\
\hline & awa3 &, $72(11,64)^{*}$ & & & & \\
\hline & awa4 & - & & & & \\
\hline & awa5 &, $78(16,71)^{*}$ & & & & \\
\hline \multirow{5}{*}{$\begin{array}{l}\text { BRAND ATTITUDE } \\
\text { (ATT) }\end{array}$} & att1 &, $82(15,20)^{*}$ & \multirow{5}{*}{, 83} & \multirow{5}{*}{90} & \multirow{5}{*}{90} & \multirow{5}{*}{,69 } \\
\hline & att2 & ,90 $(18,76)^{*}$ & & & & \\
\hline & att3 & - & & & & \\
\hline & att4 &, $85(15,73)^{*}$ & & & & \\
\hline & att5 &, $75(14,20)^{*}$ & & & & \\
\hline \multirow{4}{*}{$\begin{array}{l}\text { SATISFACTION } \\
(\text { SAT })\end{array}$} & sat1 &, $90(19,30)^{*}$ & \multirow{4}{*}{, 88} & \multirow{4}{*}{,93 } & \multirow{4}{*}{,93 } & \multirow{4}{*}{,76 } \\
\hline & sat2 &, $85(16,63)^{*}$ & & & & \\
\hline & sat3 &, $89(17,53)^{*}$ & & & & \\
\hline & sat4 &, $84(17,16)^{*}$ & & & & \\
\hline & att_11 &, $75(-)^{\#}$ & & & & \\
\hline ATTITUDINAL LOYALTY & att_12 & ,90 $(16,40)^{*}$ & & & & \\
\hline$($ ATT_L $)$ & att_13 &, $78(16,40)^{*}$ &, 81 & ,88 & 89, & 68 \\
\hline & att_14 &, $83(16,40)^{*}$ & & & & \\
\hline & pur1 &, $87(20,74)$ & & & & \\
\hline PURCHASE INTENT & pur2 &, $78(15,51)^{*}$ & 81 & 87 & 88 & \\
\hline$($ PUR $)$ & pur3 &, $77(17,44)^{*}$ & , & , &, 88 & (6), \\
\hline & pur4 &, $79(17,49)^{*}$ & & & & \\
\hline & $\exp 1$ &, $76(-)^{\#}$ & & & & \\
\hline $\begin{array}{l}\text { EXPENDITURE LEVEL } \\
\text { (EXP) }\end{array}$ & $\exp 2$ &, $80(13,94)^{*}$ &, 78 &, 80 &, 80 &, 57 \\
\hline & $\exp 3$ &, $70(13,08)^{*}$ & & & & \\
\hline & wom 1 &, $87(-)^{\#}$ & & & & \\
\hline WORD-OF-MOUTH & wom2 &, $86(19,75)^{*}$ & & & & \\
\hline$(\mathrm{WOM})$ & wom3 &, $81(20,26)^{*}$ &, 85 & ,89 & ,89 & 68 \\
\hline & wom4 &, $75(17,88)^{*}$ & & & & \\
\hline & att_l &, $88(13,52)^{*}$ & & & & \\
\hline LOYALTY & pur & ,94 $(18,12)^{*}$ & 88 & 93 & 93 & 76 \\
\hline ( $2^{\text {nd }}$ order, reflective) & $\exp$ & ,91 $(14,83)^{*}$ &, 88 & ,93 & ,93 &,$/ 6$ \\
\hline & wom &, $80(15,15)^{*}$ & & & & \\
\hline & & roodness of fit indicato & & & & \\
\hline & BBNFI & BBNNFI & CFI & IFI & RN & \\
\hline$S-B \chi 2(450)=797,521(p=, 00)$ &, 887 & ,941 & 947 &, 947 & & \\
\hline
\end{tabular}

Note: ${ }^{*}=p<.01 ;-=$ Eliminated item; ${ }^{\#=}$ parameter set at 1 to identify the second order factor; CR = Composite reliability; $\mathrm{AVE}=$ Average Variance Extracted 
Table 2 demonstrates the high internal consistency of the constructs. In each case, reliability indicators were higher than their corresponding desirable values. Cronbach's alpha exceeded Nunnally and Bernstein's (1994) recommendation of .80, Composite Reliability was higher than .60 (Bagozzi \& Yi, 1988) and the calculation of Average Variance Extracted (AVE) resulted in values greater than .50 (Fornell \& Larcker, 1981). As evidence of convergent validity, the CFA results indicate that all items are significantly $(\mathrm{p}<.01)$ related to their hypothesized factors, and all standardized loadings are higher than .60 (Bagozzi \& Yi, 1988) and the averages of the item-to-factor loadings are higher than .70 (Hair et al., 2005).

Finally, the measurement model was checked to ensure discriminant validity. Firstly, it was found that inter-factor correlations were significantly below one, through calculation of the corresponding confidence intervals (F-value \pm two standard errors, see Table 3) (Anderson \& Gerbing, 1988); secondly, for each pair of factors, it was verified that the difference of $\chi 2$ between the proposed measurement model and a restricted model where the correlation between said factors was set at 1 (Fornell \& Larcker, 1981) was significant. Finally, the Variance Extracted test (Fornell \& Larcker, 1981) showed that AVE for each factor was higher than the square of the coefficients of correlation with each of the other factors (this condition was fulfilled for every factor, except AWA-ATT and AWA-LOY, see Table 3). Thus, the overall positive results of the three tests make it possible to confirm the measurement model's discriminant validity.

Table 3

\section{Discriminant validity}

\begin{tabular}{|c|c|c|c|c|c|}
\hline & CSR & AWA & ATT & SAT & LOY \\
\hline CSR & ,69 &, 11 &, 25 & ,26 & ,28 \\
\hline AWA & {$[, 22 ;, 44]$} &, 57 & ,67 & ,37 & ,70 \\
\hline ATT & {$[, 40 ;, 60]$} & {$[, 75 ;, 88]$} & ,69 & ,70 & ,48 \\
\hline SAT & {$[, 41 ;, 61]$} & {$[, 50 ;, 72]$} & {$[, 75 ;, 92]$} & ,76 &, 50 \\
\hline LOY & {$[, 43 ;, 62]$} & {$[, 56 ;, 73]$} & {$[, 63 ;, 76]$} & {$[, 62 ;, 79]$} &, 76 \\
\hline
\end{tabular}

Note: The diagonal shows the AVE; below the diagonal are the 95\% confidence intervals; above the diagonal are the squared correlations.

\section{Results}

Table 4 shows the standardised coefficients of the structural relations contrasted with their associated $t$ value and the verification of the corresponding hypotheses. 
Table 4

Structural Equations Model. Hypothesis testing

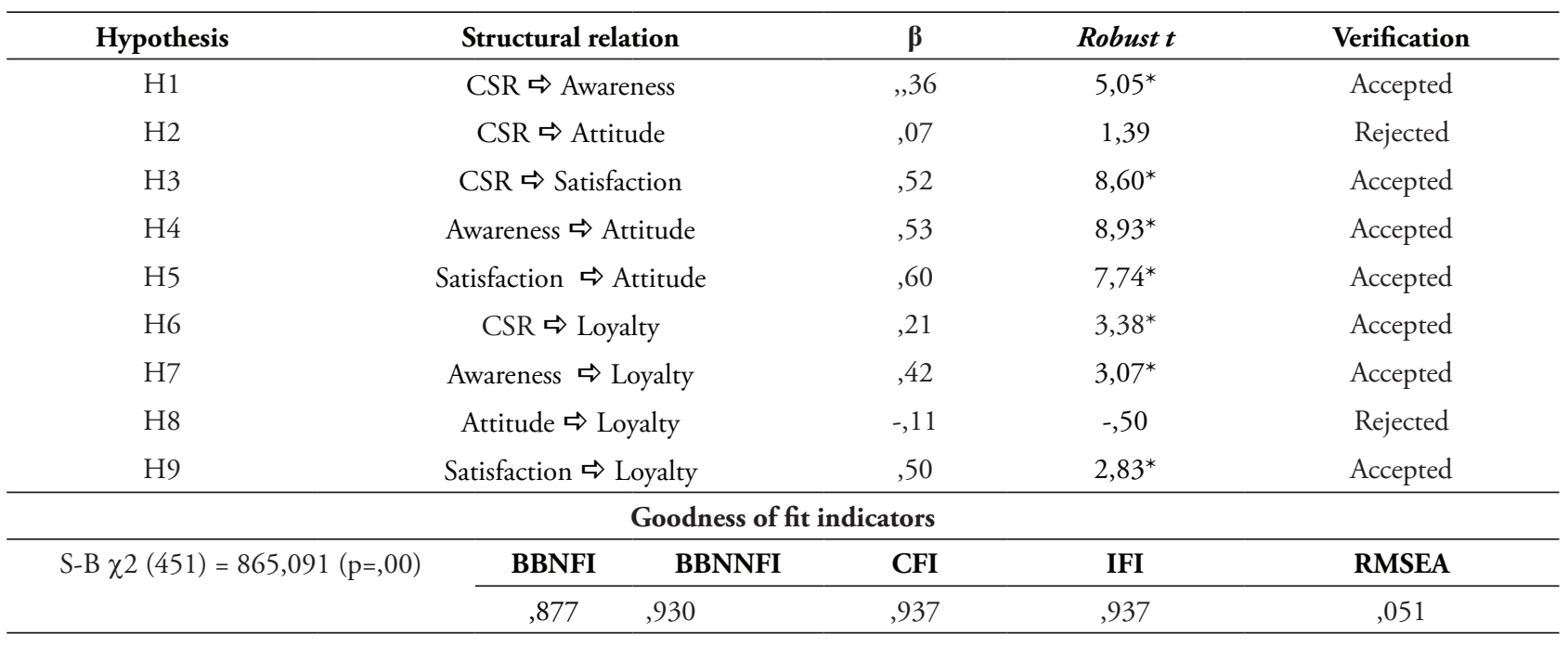

$*=p<.01$

$\mathrm{R}^{2}($ Awareness $)=.13 ; \mathrm{R}^{2}($ Satisfaction $)=.27 ; \mathrm{R}^{2}($ Attitude $)=.83 ; \mathrm{R}^{2}$ (Loyalty) $=.57$

The goodness of fit measurements for the structural model show good global fit $(\mathrm{BBNFI}=.877 ; \mathrm{BBNNFI}=.930 ; \mathrm{CFI}=.937$; IFI=.937; RMSEA=.051). In addition, the Lagrange multipliers test did not suggest the inclusion of any new structural variable between the latent variables and so the proposed theoretical model was regarded as valid.

As for the role of variables mediating the influence of perception of CSR associations on consumer loyalty, the results suggest that brand CSR associations significantly influence brand awareness $(b=.36 ; \mathrm{p}<.01 ; \mathrm{H} 1$ supported) and consumer satisfaction with the brand $(b=.52$; $\mathrm{p}<.01 ; \mathrm{H} 3$ supported). However, in contrast to the suggestion in $\mathrm{H} 2$, CSR associations are not a significant antecedent of brand attitude $(\mathrm{b}=$ .07; p>.1; H2 rejected), probably due to the fact that their role in forming attitude is diminished by the preponderant role of awareness $(b=.53$; $\mathrm{p}<.01$; H4 supported) and brand satisfaction $(\mathrm{b}=.60 ; \mathrm{p}<.01 ; \mathrm{H} 5$ supported $)$. Two further explanations might be attributed. First, when consumers are aware of the CSR practices they might consider this a required initiative as part of the current social role of brands. Second, a lack of responsibility or even irresponsibility (Riera \& Iborra, 2017) might mitigate the influence on brand attitude.

Secondly, in the present study context, perception of CSR associations is able to generate, although with less intensity, greater consumer loyalty $(\mathrm{b}=.21 ; \mathrm{p}<.01 ; \mathrm{H} 6$ accepted $)$. Awareness $(\mathrm{b}=.42 ; \mathrm{p}<.01 ; \mathrm{H} 4$ supported $)$ and consumer brand satisfaction $(\mathrm{b}=.50 ; \mathrm{p}<.01 ; \mathrm{H} 4$ accepted) are powerful antecedents of loyalty; however, remarkably, brand attitude does not appear to be a leading predictor of consumer loyalty ( $\mathrm{b}=-.11 ; \mathrm{p}>.1 ; \mathrm{H} 8$ rejected). Similarly to the reasoning shown for $\mathrm{H} 2$, this result highlights that consumers do not currently attribute value to their attitude towards the brand based on CSR, probably due to the fact that the social role is required as a social norm, rather than an exceptional initiative. Also, the higher influence of brand awareness and satisfaction might mitigate the influence of brand attitude on loyalty. These results are shown in graphic form in Figure 2. 


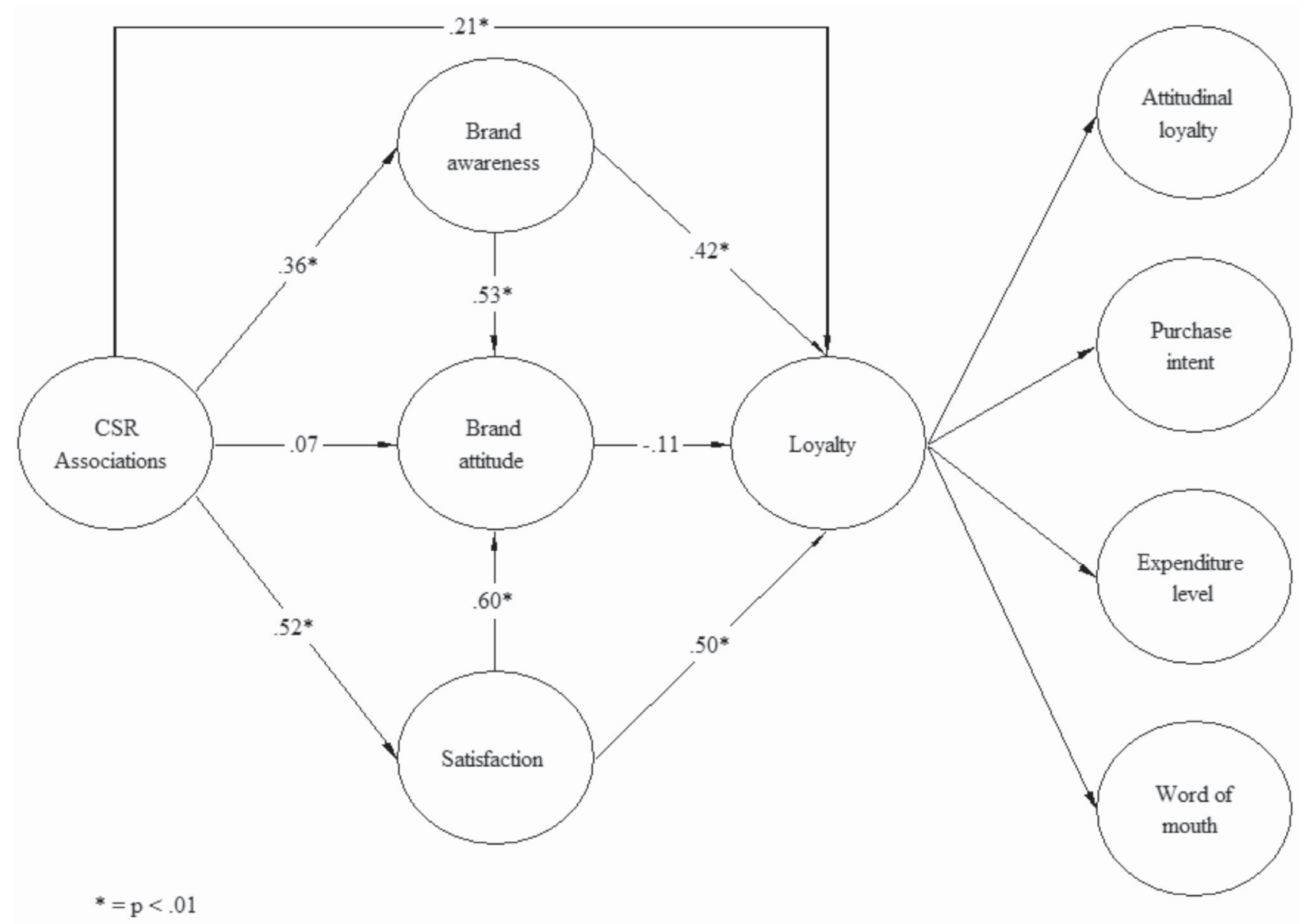

Figure 2. Final estimated model

\section{Conclusions and Implications}

The following are the main conclusions to be extracted from this research. First, sportswear consumers react positively overall in their purchase behaviour to corporate social responsibility actions. These consumers relate to the social dimension of the brand through different complementary variables: increased enjoyment of social satisfaction, increased recognition of the brand's social awareness, and social behaviour encouraged through loyalty as a variable in turn composed of positive reactions in attitudinal loyalty, purchase intention, level of expenditure and intention to recommend. Finally, the CSR actions of sportswear brands increase the intensity of the positive relationship between CSR and loyalty through awareness and satisfaction; but brand attitude does not increase or encourage CSR in its relationship with loyalty ( $\mathrm{H} 2$ and $\mathrm{H} 8$ rejected). It appears, in our model, that satisfaction, awareness and loyalty (with its attitudinal component) are eclipsing the supposed role of attitude towards the socially responsible brand. This may well be due to the fact that this study omitted from the analysis of antecedents of CSR brand attitudes other constructs such as trust, brand identification and legitimation (altruistic attribution).

This research attempts to provide deep, valuable insights for both academics and practitioners regarding CSR associations and customer loyalty. According to our results, when companies adopt CSR, consumers are willing to be loyal to the brand. More importantly, this study shows that loyalty is driven by two key 
marketing variables, namely brand awareness and satisfaction. Therefore, the gain of adopting CSR affects loyalty and, more interestingly, the study shows which variables are driven by this relationship. The double route of CSR associations to brand loyalty, which is direct and indirect through brand awareness and consumer satisfaction, not only provides robustness to the relationship but also shows which variables are eliciting this relationship.

Furthermore, we found that attitude does not have a significant influence on the effect of CSR on loyalty. This result might shed light on the usefulness of measuring attitudes towards brands with CSR. We argue that attitude does not accurately capture the influence of CSR on loyalty due to two potential explanations. First, consumers may be sceptical of the true motives for a company adopting CSR. Second, social responsibility is seen by consumers as part of current companies' social roles and in turn do not value this highly in their decision to be loyal to brands.

The results of this research and the results of the model of CSR and consumer behaviour suggest a number of conclusions and implications for strategic and business management. First, the role of CSR as a source of competitive advantage is confirmed by the increase in brand value and differential positioning through greater consumer recognition of the firm's social actions and the repercussion on purchase behaviour. Second, it is important to construct marketing strategies that integrate CSR with consumer orientation using the three dimensions of the model validated in the study (brand awareness, satisfaction and the many dimensions of loyalty) and do so in an integrated way.

Third, therefore, the results of this study suggest reinforcing CSR actions which improve the impact on brand attitude and from attitude to brand loyalty with its four explanatory subvariables: attitudinal loyalty, purchase intention, expenditure level and intention to recommend. Compliance with this objective would be aided by developing relational marketing tools to segment consumers in relation to their social profiles, which integrate the dimension of social purchase behaviour.

This research also has limitations, in addition to the one already mentioned concerning the non-integration in the model of other antecedents of attitude (in addition to brand awareness and brand satisfaction) such as trust and identification with the brand. For example, in relation to the greater or lesser complexity of the model, one possible limitation could be that of not exploring consumer responses to different forms of CSR (Green \& Peloza, 2011), and not exploring the creation of more efficient ways of measuring the value that consumers receive from an exchange.

The conclusions and limitations of this study suggest the need to address new lines of research to study the subjects dealt with here in greater depth, for example by applying the model to industries other than sportswear, where global brands predominate, for example to a mass popular consumption market; or the need to explore possible consumer priorities for certain types of CSR in their purchase decision and how they make it.

\section{References}

Aldás, J., Andreu, L., \& Currás, R. (2013). La responsabilidad social como creador de valor de marca: el efecto moderador de la atribución de objetivos. Revista Europea de Dirección y Economía de la Empresa, 22, 21-28.

Alvarado, A., Bigné, E., Currás, R., \& Aldás, J. (2010). Does Corporate Social Responsibility really add value to consumer? In Louche, C., Idowu, S. Leal, W. (eds.), Innovative Corporate Social Responsibility. From risk management to value creation, (173-193). Sheffield (UK): Greenleaf Publishing.

Alvarado-Herrera, A., Bigne, E. Aldas-Manzano, J. \& Curras-Perez, R. (2017). A scale for 
measuring consumer perception of Corporate Social Responsibility following the Sustainable Development paradigm. Journal of Business Ethics, 140(2), 243-262.

Anisimova, T. A. (2007). The effects of corporate brand attributes on attitudinal and behavioural consumer loyalty. Journal of Consumer Marketing, 24(7), 395-405.

Bagozzi, R., \& Yi, J. (1988). On the evaluation of structural equation models. Journal of the Academy of Marketing Science, 16(2), 74-94.

Barrena, J., López, M. \& Romero P.M. (2016). Corporate social responsibility: Evolution through institutional and stakeholder perspectives. European Journal of Management and Business Economics, 25, 8-14.

Beckmann, S. (2007). Consumer and Corporate Social Responsibility, matching the unmatchable. Australasian Marketing Journal, 15(1), 27-36.

Bennett, R. \& Rundle-Thiele, S.R. (2002). Measuring attitudinal brand loyalty. Journal of Brand Management, 9(3), 193-209.

Bentler, P., \& Bonnet, D. (1980). Significance tests and goodness of fit in the analysis of covariance structures. Psychological Bulletin, 88, 588-606.

Bentler, P. (2005). EQS 6, Structural Equation Program Manual. Multivariate Software, Encino, CA.

Bhattacharya, C., \& Sen, S. (2003). ConsumerCompany Identification: a framework for understanding consumers' relationships with companies. Journal of Marketing, 67, 76-88.

Bhattacharya, C. B., \& Sen, S. (2004). Doing better at doing good. When, why, and how consumers respond to corporate social initiatives. California Management Review, 47(1), 9-24.

Bhattacharya, C., Korschun, D., \& Sen, S. (2009). Strengthening stakeholder-company relationships through mutually beneficial Corporate Social Responsibility initiatives. Journal of Business Ethics, 85(2), 257-272.

Bigné, E., Chumpitaz, R., \& Currás, R. (2010). Alliances between brands and social causes: the influence of company credibility on social responsibility image. Journal of Business Ethics, 96(2), 169-186.

Bolton, R. N., \& Drew, J. H. (1991). A longitudinal analysis of the impact of service changes on customer attitudes. Journal of Marketing, 55, 1-9.

Bowen, H.R. (1953). Social responsibilities of the businessman. New York: Harper \& Row.

Brown, T. J., \& Dacin, P. (1997). The company and the product. Corporate beliefs and consumer product responses. Journal of Marketing, 61(1), 68-84.

Brunner, T. A. Stocklin, M. \& Opwis, K. (2008). Satisfaction, image and loyalty: new versus experienced customers. European Journal of Marketing, 42(9/10), 1095-1105.

Carroll, A.B. (1979): A three-dimensional conceptual model of corporate performance. The Academy of Management Review, 4(4), 497-505.

Cha, M.K., Yi, Y., \& Bagozzi, R.P. (2016). Effects of customer participation in Corporate Social Responsibility (CSR) programs on the CSRBrand fit and brand loyalty. Cornell Hospitality Quarterly, 57(3), 235-249.

Chaudhuri, A., \& Holbrook, M. B. (2001). The chain of effects from brand trust and brand affect to brand performance, the role of brand loyalty. Journal of Marketing, 65(2), 81-93.

Chen, YS. \& Chang, CH. (2013). Greenwash and green Trust: The mediation effects of green consumer confusion and green perceived risk. Journal of Business Ethics, 114(3), 489-500. 
Chou, C., Bentler, P., \& Satorra, A. (1991). Scaled test statistics and robust standard errors for non-normal data in covariance structure analysis, a Monte Carlo study. The British Journal of Mathematical and Statistical Psychology, 44(2), 347-357.

Cronbach, L. (1951). Coefficient alpha and the internal structure of tests. Psychometrika, 16, 297-334.

Cronin, J.J., Brady, M.K., \& Hult, G. (2000). Assessing the effects of quality, value, and customer satisfaction on consumer behavioral intentions in service environments. Journal of Retailing, 76(2), 193-218.

Crosby, L., \& Stephen, N. (1987). Effects of relationship marketing on satisfaction, retention, and prices in the insurance industry. Journal of Marketing Research, 24, 404-411.

Dabholkar, P.A., \& Bagozzi, R.P. (2002). An attitudinal model of technology based selfservice: moderating effects of consumer traits and situational factors. Journal of the Academy of Marketing Science, 30, 184-201.

Dean, D.H. (2003). Consumer perception of corporate donations: Effects of company reputation for social responsibility and type of donation. Journal of Advertising, 32(4), 91-102.

Diehl, S., Terlutter, R., \& Mueller, B. (2016). Doing good matters to consumers: the effectiveness of humane-oriented CSR appeals in cross-cultural standardized advertising campaigns. International Journal of Advertising, 35(4), 730-757.

Du S., Bhattacharya C.B., \& Sen, S. (2007). Reaping relational rewards from corporate social responsibility. The Role of competitive positioning. International Journal of Research in Marketing, 24, 224-241.

Du S., Bhattacharya C.B., \& Sen S. (2010). Maximizing business returns to Corporate
Social Responsibility (CSR). The role of CSR communication. International Journal of Management Reviews, 12(1), 8-19.

Ellen P. S., Webb D. J., Mohr L. A. (2006). Building corporate associations: Consumer attributions for corporate socially responsible programs. Journal of the Academy of Marketing Science, 34(2), 147-157.

Ehrenberg, A.S.C., Goodhardt, G.J. \& Barwise, T.P. (1990). Double jeopardy revisited. Journal of Marketing, 54, 82-91.

Flavián, C., Guinalíu, M., \& Gurrea, R. (2006). The role played by perceived usability, satisfaction and consumer trust on website loyalty. Information \& Management, 43, 1-14.

Forehand, M., \& Grier, S. (2003). When is honesty the best policy? The effect of stated company intent on consumer skepticism. Journal of Consumer Psychology, 13(3), 349-356.

Fornell, C., \& Larcker, D. (1981). Evaluating structural equations models with unobservable variables and measurement error. Journal of Marketing Research, 18, 39-50.

Frenkel, S. (2001). Globalization, athletic footwear commodity chains and employment relations in China. Organization Studies 22(4), 531-562.

García de los Salmones M. M., Herrero C. A., \& Rodríguez del Bosque I. (2005). Influence of Corporate Social Responsibility on loyalty and valuation of services. Journal of Business Ethics, $61,369-385$.

Green, T., \& Peloza, J. (2011). How does corporate social responsibility create value for consumers? Journal of Consumer Marketing, 28(1), 48-56.

Hair, J., Black, W., Babin, B., Anderson, R., \& Tatham, R. (2005). Multivariate Data Analysis. New Jersey, Prentice Hall. 
Hatch, M.J., \& Schultz, M. (2003). Bringing the corporation into corporate branding. European Journal of Marketing, 37(7/8), 1041-64.

He H., \& Li Y. (2011). CSR and service brand. The mediating effect of brand identification and moderating effect of service quality. Journal of Business Ethics, 100, 673-688.

Hoeffler, S., \& Keller, K.L. (2002). Building brand equity through corporate societal marketing. Journal of Public Policy \&Marketing, 21(1), 78-89.

Homburg, C., Koschate, N., \& Hoyer, W.D. (2005). Do satisfied customers really pay more? A study of the relationship between customer satisfaction and willingness to pay. Journal of Marketing, 69, 84-97.

Jacoby J., \& Kyner, D. B. (1973). Brand loyalty vs. repeat purchasing behavior. Journal of Marketing Research, 10(1), 1-9.

Jones, T.M. (1980). Corporate social responsibility revisited, redefined. California Management Review, 22(3), 59-67.

Lacey, R., Kennett-Hensel, P., \& Manolis, C. (2015). Is corporate social responsibility a motivator or hygiene factor? Insights into its bivalent nature. Journal of the Academy of Marketing Science, 43(3), 315-332.

Lafferty, B. (2007). The relevance of fit in a cause-brand alliance when consumers evaluate corporate credibility. Journal of Business Research, 60, 447-453.

Liu, M.T., Wong, I. A., Shi, G., Chu, R., \& Brock, J.M. (2014). The impact of corporate social responsibility (CSR) performance and perceived brand quality on customer-based brand preference. Journal of Services Marketing, 28(3), 181-194.

Luo, X., \& Bhattacharya, C.B. (2006). Corporate Social Responsibility, customer satisfaction, and market value. Journal of Marketing, 70, 1-18.
Madrigal, R., \& Boush, D.M. (2008). Social responsibility as a unique dimension of brand personality and consumers' willingness to reward. Psychology \& Marketing, 25(6), 538-564.

Maignan, I. (2001). Consumer perceptions of corporate social responsibility: a cross cultural comparison. Journal of Business Ethics, 30(1), 57-73.

Maignan I., \& Ferrell O. C. (2001). Corporate citizenship as a marketing instrument. Concepts, evidence and research directions. European Journal of Marketing, 35(3/4), 457-484.

Maignan I., Ferrell O.C., \& Hult, G.T. (1999). Corporate Citizenship, cultural antecedents and business benefits. Journal of the Academy of Marketing Science, 27(4), 455-469.

Mandhachitara, R., \& Poolthong, Y. (2011). A model of customer loyalty and corporate social responsibility. Journal of Services Marketing, 25(2), 122-133.

Marín L., Ruiz S., \& Rubio A. (2009). The role of identity salience in the effects of Corporate Social Responsibility on consumer behavior. Journal of Business Ethics, 84, 65-78.

Martínez, P., Pérez, A., \& Rodríguez del Bosque, I. (2014). CSR influence on hotel brand image and loyalty. Academia Revista Latinoamericana de Administración, 27(2), 267-283.

McWilliams, A., \& Siegel, D. (2000). Corporate Social Responsibility and financial performance, correlation or misspecification? Strategic Management Journal, 21(5), 603-609.

Mohr, L.A., \& Webb, D.J. (2005). The effects of corporate social responsibility and price on consumer responses. Journal of Consumer Affairs, 39(1), 121-47.

Nunnally, J., \& Bernstein, I. (1994). Psychometric theory. McGraw-Hill, New York. 
Oliver, R. L. (1980). A cognitive model of the antecedents and consequences of satisfaction decisions. Journal of Marketing Research, 17, 460-469.

Oliver, R.L. (1999): Whence consumer loyalty? Journal of Marketing, 63, 33-44.

Peloza, J., \& Shang, J. (2011). How can corporate social responsibility activities create value for stakeholders? A systematic review. Journal of the Academy of Marketing Science, 39, 117-135.

Riera, M., \& Iborra, M. (2017). Corporate social irresponsibility: review and conceptual boundaries. European Journal of Management and Business Economics, 26(2), 146-162.

Sen, S., \& Bhattacharya, C. B. (2001). Does doing good always lead to doing better? Consumer reactions to Corporate Social Responsibility. Journal of Marketing Research, 38(2), 225-244.

Schouten, J. W. \& McAlexander, J.H. (1995). Subcultures of consumption: An Ethnography of the new bikers. Journal of Consumer Research, 22, 43-61.

Swaen V., \& Chumpitaz R. (2008). Impact of Corporate Social Responsibility on consumer trust. Recherche \& Applications en Marketing, 23(4), 7-27.
Szymanski, D. M., \& Henard, D. (2001). Customer satisfaction. A meta-analysis of the empirical evidence. Journal of the Academy of Marketing Science, 29, 16-35.

Torres, A., Bijmolt, T.H.A., Tribó, J.A., \& Verhoef, P. (2012). Generating global brand equity through Corporate Social Responsibility to key stakeholders. International Journal of Research in Marketing, 29, 13-24.

Turker, D. (2009). Measuring Corporate Social Responsibility: A scale development study. Journal of Business Ethics, 85(4), 411-427.

van Marrewijk, M. (2003). Concepts and definitions of CSR and corporate sustainability: between agency and communion. Journal of Business Ethics, 44(2-3), 95-105.

Yoo, B., Donthu, N., \& Lee, S. (2000). An examination of selected marketing mix elements and brand equity. Journal of the Academy of Marketing Science, 28(2), 195-211.

Zeithaml, V. A., Berry, L. L., \& Parasuraman, A. (1996). The behavioral consequences of service quality. Journal of Marketing, 60, 31-46. 


\section{Appendix. Scales used}

\section{The brand of your preference...}

\section{CSR Associations}

csr1. Tries to manage economic resources well

csr2. Tries to improve the working conditions of collaborators

csr3. Tries to contribute to the improvement of the communities in which it works

csr4. Tries to make contributions to social causes

csr5. Tries to promote environmental sustainability

csr6. Tries to behave in an ethically responsible manner

\section{Brand Awareness}

awa1. It is a well-known brand in its sector

awa2. The brand is appropriate for sportswear

awa3. I can easily recognize it among others in the sector

awa4. I can quickly remember its logo

awa5. It has unique products

\section{Brand Attitude}

att1. I think it is a brand that offers products with good performance

att 2 . It is a brand I can rely on

att3. I find it is a brand that offers good value for money

att4. I think it is a brand with a good image

att5. I think it is a suitable brand for sportswear

\section{Customer Satisfaction}

sat 1 . The brand meets my expectations

sat 2 . The brand has the expected quality

sat3. I am satisfied to buy this brand

sat4. I have done the right thing by buying this brand

\section{Attitudinal Loyalty}

att_11. It fits my personality

att_12. I consider myself loyal to this brand

att_13. If I do not find this brand, I prefer to wait to find it to make my purchase

att_14. I prefer to continue with my reference brand rather than trying other brands

\section{Purchase Intention}

pur1. I consider my reference brand as my first choice when buying sportswear

pur2. I will buy my reference brand in my next purchases of sportswear

pur3. Given equal characteristics with other brands, I prefer to buy my reference brand

pur4. I do not buy another brand if my reference brand is available in the store

\section{Expenditure Level}

exp1. I am willing to spend more on this brand than on other brands

exp2. I spend most of my budget on sportswear on this brand

exp3. I spend more on this brand than on the sportswear of other brands because it lasts longer

exp4. If the price of my brand's sportswear is increased, I do not stop buying it

\footnotetext{
Word of Mouth

wom1. I say positive things about the brand to other people

wom2. I recommend the brand to those who ask for my opinion

wom3. I motivate friends and family to buy the brand

wom4. I communicate to others the promotions of the brand
} 
About the Authors:

1. José Javier Rivera PhD, CEO of Stravalue International and former Part-Time Professor, University of Valencia, Valencia, Spain, j.javier.rivera@uv.es

\section{ORCID}

(iD) 0000-0002-9358-1590

2. Enrique Bigne PhD, Professor, University of Valencia, Valencia, Spain, enrique.bigne@uv.es

ORCID

(iD) 0000-0002-6529-7605

3. Rafael Curras-Perez PhD, Associate Professor, University of Valencia, Valencia, Spain, rafael.curras-perez@uv.es

ORCID

(iD) 0000-0002-3092-8235

Has any preliminary version of this article been presented / published in annals of scientific congresses or is it derived from a thesis or dissertation? Yes

If yes, please enter below the information regarding these preliminary publications (Title of the article, Authors, Name of the Event, Place and Date)

Rivera, J.J., Bigne, E, \& Curras-Perez, R. (2013). Model of consumer relationships with brand social dimension: effects of Corporate Social Responsibility on brand loyalty. 8th Global Brand Conference of the AM Brand, Corporate Identity and Reputation Special Interest Group, Oporto, Portugal, 3-5 April 2013.

\section{Contribution of each author}

Each author should take responsibility for at least one component of the paper. If the article is approved for publication, the authors should indicate in the diagram below, what was the contribution of each.

\begin{tabular}{|c|c|c|c|}
\hline Contribution & Rivera & Bigne & Currás \\
\hline 1. Definition of research problem & $\sqrt{ }$ & $\sqrt{ }$ & $\sqrt{ }$ \\
\hline 2. Development of hypotheses or research questions (empirical studies) & $\sqrt{ }$ & $\sqrt{ }$ & $\sqrt{ }$ \\
\hline 3. Development of theoretical propositions (theoretical work) & $\sqrt{ }$ & $\sqrt{ }$ & \\
\hline 4. Theoretical foundation/ Literature review & $\sqrt{ }$ & $\sqrt{ }$ & $\sqrt{ }$ \\
\hline 5. Definition of methodological procedures & $\sqrt{ }$ & $\sqrt{ }$ & $\sqrt{ }$ \\
\hline 6. Data collection & $\sqrt{ }$ & & \\
\hline 7. Statistical analysis & $\sqrt{ }$ & $\sqrt{ }$ & $\sqrt{ }$ \\
\hline 8. Analysis and interpretation of data & $\sqrt{ }$ & $\sqrt{ }$ & $\sqrt{ }$ \\
\hline 9. Critical revision of the manuscript & $\sqrt{ }$ & $\sqrt{ }$ & $\sqrt{ }$ \\
\hline 10. Manuscript writing & $\sqrt{ }$ & $\sqrt{ }$ & $\sqrt{ }$ \\
\hline 11. Other (please specify which) & & & \\
\hline
\end{tabular}

This information will be available in publications as end notals in accordance with the criteria, policies and procedures for admission and permanence of scientific journals in SciELO Brazil Collection. 